\title{
Saccharomonospora marina sp. nov., isolated from an ocean sediment of the East China Sea
}

\author{
Correspondence \\ Wen-Jun Li \\ wjli@ynu.edu.cn \\ Yao-Jian Huang \\ yjh@xmu.edu.cn
}

\author{
Zui Liu, ${ }^{1} \dagger$ Yan $\mathrm{Li}^{2}{ }^{2}+$ Liu-Qiang Zheng, ${ }^{2}$ Yao-Jian Huang ${ }^{1}$ \\ and Wen-Jun $\mathrm{Li}^{2,3}$
}
${ }^{1}$ The Key Laboratory of Ministry of Education of Cell Biology and Tumor Engineering, School of Life Science, Xiamen University, Xiamen 361005, PR China
${ }^{2}$ The Key Laboratory for Microbial Resources of the Ministry of Education and Laboratory for Conservation and Utilization of Bio-resources, Yunnan Institute of Microbiology, Yunnan University, Kunming, Yunnan 650091, PR China
${ }^{3}$ Guangdong Key Laboratory of Marine Materia Medica, South China Sea Institute of Oceanology, Chinese Academy of Sciences, Guangzhou 510301, PR China

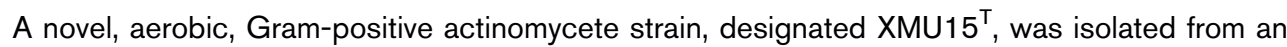
ocean sediment collected from Zhaoan Bay in the East China Sea and was subjected to a polyphasic approach to determine its taxonomic position. The isolate grew optimally at $28{ }^{\circ} \mathrm{C}$ and at $\mathrm{pH} 7.0$ in the presence of $3 \%(\mathrm{w} / \mathrm{v}) \mathrm{NaCl}$ on ISP medium 2. Gelatin liquefaction, milk coagulation and nitrate reduction were positive. Cellulose and starch hydrolysis, hydrogen sulfide and melanin production, and catalase, urease and oxidase activities were negative. The predominant menaquinone of the isolate was MK-9 $\left(\mathrm{H}_{4}\right)$, and meso-diaminopimelic acid was the diagnostic amino acid in the cell wall. The phospholipids of the isolate comprised diphosphatidylglycerol, phosphatidylglycerol, phosphatidylinositol, and a minor amount of phosphatidylethanolamine. The major fatty acids of the strain were iso- $\mathrm{C}_{16: 0}(26.36 \%)$, $\mathrm{C}_{17: 1} \omega 6 c(16.80 \%), \mathrm{C}_{15: 0}(16.2 \%), \mathrm{C}_{16: 0}(8.90 \%), \mathrm{C}_{17: 1} \omega 8 c(7.69 \%)$ and iso- $\mathrm{C}_{16: 1} \mathrm{H}$ $(5.95 \%)$. The DNA G $+\mathrm{C}$ content of the genomic DNA was $68.1 \mathrm{~mol} \%$. A phylogenetic tree based on 16S rRNA gene sequences showed that the isolate fell within the evolutionary radiation encompassed by the genus Saccharomonospora and showed the highest 16S rRNA gene sequence similarity $(96.7 \%)$ to Saccharomonospora xinjiangensis DSM $44391^{\top}$. Based on the results of $16 \mathrm{~S}$ rRNA gene sequence analysis and phenotypic and genotypic characterization, strain XMU15 ${ }^{\top}\left(=\right.$ KCTC $19701^{\top}=$ CCTCC AA 209048 $\left.{ }^{\top}\right)$ represents a novel species of the genus Saccharomonospora, for which the name Saccharomonospora marina sp. nov. is proposed.
\end{abstract}

The genus Saccharomonospora, which belongs to the family Pseudonocardiaceae, was established by Nonomura \& Ohara (1971). At the time of writing, the genus comprises eight recognized species, Saccharomonospora viridis (Nonomura \& Ohara, 1971), Saccharomonospora azurea (Hu, 1987), Saccharomonospora glauca (Greiner-Mai et al., 1988), Saccharomonospora cyanea (Runmao et al., 1988), Saccharomonospora xinjiangensis (Jin et al., 1998), Saccharomonospora halophila (Al-Zarban et al., 2002),

†These authors contributed equally to this work.

The GenBank/EMBL/DDBJ accession number for the 16S rRNA gene sequence of strain $\mathrm{XMU}^{\mathrm{T}} \mathrm{5}^{\mathrm{T}}$ is FJ812357.

A scanning electron micrograph showing spores of strain $\mathrm{XMU}^{\mathrm{T}} \mathrm{5}^{\mathrm{T}}$, and tables detailing cultural characteristics and signature nucleotide analysis results are available with the online version of this paper.
Saccharomonospora paurometabolica (Li et al., 2003) and Saccharomonospora saliphila (Syed et al., 2008). The members of the genus are aerobic, Gram-positive and non-acid-fast. The hydrolysates of the whole cells contain meso-diaminopimelic acid, major amounts of galactose and arabinose (some strains also have ribose) and MK-9 $\left(\mathrm{H}_{4}\right)$ as the predominant menaquinone.

Strain $\mathrm{XMU}^{\mathrm{T}}{ }^{\mathrm{T}}$ was isolated from an ocean sediment sample collected from Zhaoan Bay in the East China Sea (GPS coordinates for the sample site are $117^{\circ} 17.64^{\prime}$ E $23^{\circ}$ $66.5^{\prime} \mathrm{N}$, at a depth of $4 \mathrm{~m}$ ) after being incubated on PLAemulsified agar (Pranamuda \& Tokiwa, 1999) at $28{ }^{\circ} \mathrm{C}$ for 4 weeks. The isolate was preserved on International Streptomyces Project medium 2 (ISP 2, Shirling \& Gottlieb, 1966) slants at $4{ }^{\circ} \mathrm{C}$ and in $20 \%(\mathrm{v} / \mathrm{v})$ glycerol at $-80{ }^{\circ} \mathrm{C}$. Morphology was observed by light microscopy 
(BH 2; Olympus) and scanning electron microscopy (JSM5600LV; JEOL) after 14 days of growth on ISP medium 2 agar at $28{ }^{\circ} \mathrm{C}$. Substrate and aerial mycelia were well developed. Smooth or wrinkled spores were produced on the branched aerial mycelium singly, in pairs or occasionally in short spore-chains (See Supplementary Fig. S1 available in IJSEM online). The media used for cultural and physiological characterization were those described by Shirling \& Gottlieb (1966) and Williams et al. (1989). Cultural characteristics were determined after 4 weeks at $28{ }^{\circ} \mathrm{C}$ by methods used in the ISP (Shirling \& Gottlieb, 1966). Colours of substrate and aerial mycelia were determined by comparison with colour chips from the ISCC-NBS colour charts standard sample no. 2106 (Kelly, 1964). The isolate could be distinguished from the most closely related species of the genus Saccharomonospora, S. xinjiangensis DSM $44391^{\mathrm{T}}$, by comparing a battery of cultural characteristics (Supplementary Table S1).

Growth at different temperatures $(4,10,15,20,28,37,40$, $45,50,55,60$ and $65{ }^{\circ} \mathrm{C}$ ) was tested with ISP medium 2 ( $\mathrm{pH}$ 7.0) plates. Growth at different $\mathrm{NaCl}$ concentrations was tested by using ISP medium $2(\mathrm{pH} 7.0)$ as the basal medium with $\mathrm{NaCl}$ concentrations ranging from 0 to $15 \%$ $(\mathrm{w} / \mathrm{v})$, at intervals of $1 \%$, and incubating at $28{ }^{\circ} \mathrm{C}$ for 4 weeks. Growth was investigated between $\mathrm{pH} 4.0$ and 10.0 at intervals of $1 \mathrm{pH}$ unit, using the following buffer system in ISP 2 broth medium: $\mathrm{pH} 4.0-5.0,0.1 \mathrm{M}$ citric acid/ $0.1 \mathrm{M}$ sodium citrate; $\mathrm{pH} 6.0-8.0,0.1 \mathrm{M} \mathrm{KH}_{2} \mathrm{PO}_{4} / 0.1 \mathrm{M}$ $\mathrm{NaOH}$; pH 9.0-10.0, 0.1 M NaHCO$/ 3 / 0.1 \mathrm{M} \mathrm{Na}_{2} \mathrm{CO}_{3}$. Methods for determining catalase and oxidase activity were as described by Rivas et al. (2003). Biomass for chemical and molecular studies was obtained by cultivation in ISP medium 2 ( $\mathrm{pH} 7.0$ ) in shaking flasks (150 r.p.m.) at $28{ }^{\circ} \mathrm{C}$ for one week. The isolate showed phenotypic differences from its closest relative, S. xinjiangensis DSM $44391^{\mathrm{T}}$, when comparing a battery of morphological and physiological properties (Table 1) after being incubated at $28{ }^{\circ} \mathrm{C}$ for 4 weeks and observed once a week. The detailed morphological and physiological properties of strain $\mathrm{XMU} 15^{\mathrm{T}}$ are given in the species description.

The amino acids and sugars in cell wall hydrolysates were analysed by using the methods established by Hasegawa et al. (1983). Polar lipids were extracted, examined by using two-dimensional TLC and identified on the basis of procedures described by Minnikin et al. (1984). Isoprenoid quinones were analysed by HPLC as described by Minnikin et al. (1984) and Kroppenstedt (1982). Cellular fatty acids were determined for the novel isolate and for S. xinjiangensis DSM $44391^{\mathrm{T}}$ by means of the Microbial Identification System (MIDI; Microbial ID; Sasser, 1990) with cells grown in TSB (trypticase soy broth) medium ( $\mathrm{pH} 7.0)$ in flasks on a rotary shaker at 200 r.p.m. and at $28{ }^{\circ} \mathrm{C}$ for 3 days. Chemotaxonomic data for the new isolate was consistent with its assignment to the genus Saccharomonospora (Nonomura \& Ohara, 1971; $\mathrm{Hu}$, 1987; Greiner-Mai et al., 1988; Hu et al., 1988; Jin et al., 1998; Al-Zarban et al., 2002; Li et al., 2003; Syed et al.,
2008). The cell wall diamino acid in the peptidoglycan layer of both strains was meso-diaminopimelic acid, and the whole-cell sugars mainly comprised galactose and arabinose. The phospholipids of the isolate consisted of diphosphatidylglycerol, phosphatidylglycerol, phosphatidylinositol, and a minor amount of phosphatidylethanolamine. The menaquinones were MK- $9\left(\mathrm{H}_{4}\right)(89.6 \%)$ and MK-8 $\left(\mathrm{H}_{4}\right)(10.4 \%)$. Cellular fatty acids comprised iso$\mathrm{C}_{16: 0}(26.36 \%), \mathrm{C}_{17: 1} \omega 6 c(16.80 \%), \mathrm{C}_{15: 0}(16.2 \%), \mathrm{C}_{16: 0}$ $(8.90 \%), \mathrm{C}_{17: 1} \omega 8 c(7.69 \%)$, iso- $\mathrm{C}_{16: 1} \mathrm{H}(5.95 \%), \mathrm{C}_{17: 0}$

Table 1. Phenotypic characteristics that differentiate the novel isolate from its closest relative, Saccharomonospora xinjiangensis DSM $44391^{\top}$

Strains: 1 XMU15 ${ }^{\mathrm{T}} ; 2$, S. xinjiangensis DSM $44391^{\mathrm{T}}$. +, Positive; -, negative; $\mathrm{R}$, resistant; $\mathrm{s}$, sensitive. All data are from this study.

\begin{tabular}{|c|c|c|}
\hline Characteristic & 1 & 2 \\
\hline \multicolumn{3}{|l|}{ Degradation of: } \\
\hline Cellulose & - & + \\
\hline Starch & - & + \\
\hline \multicolumn{3}{|l|}{$\begin{array}{l}\text { Carbon source } \\
\text { utilization }\end{array}$} \\
\hline D-Glucose & + & - \\
\hline myo-Inositol & + & - \\
\hline Mannose & + & - \\
\hline Melibiose & + & - \\
\hline L-Rhamnose & + & - \\
\hline Ribose & - & + \\
\hline \multicolumn{3}{|l|}{$\begin{array}{l}\text { Nitrogen source } \\
\text { utilization }\end{array}$} \\
\hline L-Histidine & - & + \\
\hline \multicolumn{3}{|l|}{ Enzyme production } \\
\hline Autolysis & - & + \\
\hline Catalase & - & + \\
\hline \multicolumn{3}{|l|}{ Antibiotic assay } \\
\hline Carbenicillin $(10 \mu \mathrm{g})$ & $\mathrm{R}$ & s \\
\hline $\begin{array}{l}\text { Cephalothin (V) } \\
(30 \mu \mathrm{g})\end{array}$ & $\mathrm{R}$ & s \\
\hline $\begin{array}{l}\text { Cephalothin (VI) } \\
(30 \mu \mathrm{g})\end{array}$ & $\mathrm{R}$ & s \\
\hline Furoxone $(30 \mu \mathrm{g})$ & $\mathrm{R}$ & s \\
\hline Piperacillin $(10 \mu \mathrm{g})$ & $\mathrm{R}$ & s \\
\hline Menaquinones & $\begin{array}{c}\text { MK-9 }(\mathrm{H} 4)(89.6 \%) \\
\text { MK-8 }(\mathrm{H} 4) \\
(10.4 \%)\end{array}$ & $\begin{array}{c}\text { MK-9 (H4) } \\
(85.1 \%), \text { MK-8 } \\
(\mathrm{H} 4)(13.0 \%), \\
\text { MK-7(H2) } \\
(1.9 \%)\end{array}$ \\
\hline $\begin{array}{l}\text { Major fatty acids } \\
(>5.0 \%)\end{array}$ & $\begin{array}{c}\text { iso- } \mathrm{C}_{16: 0}(26.36 \%), \\
\mathrm{C}_{17: 1} \omega 6 c \\
(16.80 \%), \mathrm{C}_{15: 0} \\
(16.20 \%), \\
\mathrm{C}_{16: 0}(8.90 \%), \\
\mathrm{C}_{17: 1} \omega 8 c(7.69 \%), \\
\text { iso- } \mathrm{C}_{16: 1} \mathrm{H} \\
(5.95 \%)\end{array}$ & $\begin{array}{c}\mathrm{C}_{17: 1} \omega 8 c \\
(19.69 \%), \\
\mathrm{C}_{17: 1} \omega 6 c \\
(17.38 \%), \text { iso- } \\
\mathrm{C}_{16: 0}(14.56 \%), \\
\mathrm{C}_{16: 0}(12.31 \%), \\
\mathrm{C}_{17: 0}(6.26 \%), \\
\mathrm{C}_{15: 0}(5.91 \%)\end{array}$ \\
\hline DNA $G+C$ mol $\%$ & 68.1 & 67.7 \\
\hline
\end{tabular}


$(2.14 \%)$, anteiso- $\mathrm{C}_{17: 0}(1.87 \%), \mathrm{C}_{15: 1} \omega 6 c(1.32 \%)$ and $\mathrm{C}_{18: 1} \omega 9 c(1.24 \%)$, which is similar to those of strains of the genus Saccharomonospora.

Methods used for extraction of genomic DNA and PCR amplification of the 16S rRNA gene were as described by Li et al. (2007). Multiple alignments with sequences of the most closely related type strains of the genus Saccharomonospora and calculations of levels of sequence similarity were carried out by using the EzTaxon server 2.0 (Chun et al., 2007). Phylogenetic analysis was performed by using three tree-making algorithms, namely the neighbour-joining (Saitou \& Nei, 1987), maximum-likelihood (Felsenstein, 1981) and maximumparsimony (Fitch, 1971) methods. A phylogenetic tree was reconstructed by using the neighbour-joining method of Saitou \& Nei (1987) from $K_{\text {nuc }}$ values (Kimura, 1980) using MEGA version 4.0 (Tamura et al., 2007). The topology of the phylogenetic tree was evaluated by the bootstrap resampling method of Felsenstein (1985) with 1000 replicates. The genomic DNA of the isolate for the determination of the $G+C$ content was prepared according to the method of Marmur (1961). The $\mathrm{G}+\mathrm{C}$ content of the DNA was determined by reverse-phase HPLC of nucleosides, according to Mesbah et al. (1989), to be $68.1 \mathrm{~mol} \%$.

The 16S rRNA gene sequence of strain XMU15 ${ }^{\mathrm{T}}$ (1529 bp) was analysed by preliminary comparison with sequences from the GenBank database. The results indicated that the new isolate had the highest sequence similarity to members of the genus Saccharomonospora. Phylogenetic analysis showed that strain $\mathrm{XMU} 15^{\mathrm{T}}$ fell into a separate subclade between the genera Prauserella and Saccharomonospora (Fig. 1). The topology of the neighbour-joining tree was similar to those of the phylogenetic trees reconstructed by using the maximum-likelihood and maximum-parsimony algorithms (Fig. 1). Strain XMU15 ${ }^{\mathrm{T}}$ showed the highest $16 \mathrm{~S}$ rRNA gene sequence similarity $(96.7 \%)$ to S. xinjiangensis DSM $44391^{\mathrm{T}}$ and its morphology and chemotaxonomic data were similar to those of members of the genus Saccharomonospora. Thus, strain $\mathrm{XMU}^{\mathrm{T}}{ }^{\mathrm{T}}$ should be assigned to the genus Saccharomonospora.
Despite its phylogenetic position between the genera Saccharomonospora and Prauserella, the new isolate had highest $16 \mathrm{~S}$ rRNA gene sequence similarity to $S$. xinjiangensis DSM $44391^{\mathrm{T}}$, from which it could be distinguished by using a battery of cultural characteristics (Supplementary Table S1) and other phenotypic characteristics (Table 1). In addition, $16 \mathrm{~S}$ rRNA gene signature nucleotides of strain XMU15 ${ }^{\mathrm{T}}$ were most similar to those of the genus Saccharomonospora (Supplementary Table S2), rather than to those of the genus Prauserella. Thus, we consider strain $\mathrm{XMU} 15^{\mathrm{T}}$ to represent a novel species of the genus Saccharomonospora, for which we propose the name Saccharomonospora marina sp. nov.

\section{Description of Saccharomonospora marina sp. nov.}

Saccharomonospora marina (ma.ri'na. L. fem. adj. marina of the sea).

Aerobic, Gram-positive, non-motile actinomycete. Nonmotile smooth or wrinkled spores are produced on the branched aerial mycelium singly, in pairs and occasionally in short chains. Optimal growth occurs at $28-37{ }^{\circ} \mathrm{C}$ and at pH 7.0 on ISP medium 2. NaCl is tolerated up to $5 \%(\mathrm{w} /$ $\mathrm{v})$, with an optimum concentration of $0-3 \%(\mathrm{w} / \mathrm{v})$. DArabinose, cellobiose, D-galactose, D-glucose, myo-inositol, maltose, D-mannitol, D-mannose, melibiose, L-rhamnose, sucrose and D-xylose can be utilized as carbon sources, but lactose, sorbitol, L-sorbose, raffinose and ribose cannot. LAlanine, L-arginine, L-cystine, L-glutamate, glycine, Lleucine, L-lysine, L-methionine, L-phenylalanine, L-proline, L-serine, L-threonine, L-tyrosine and L-valine can be used as nitrogen sources, but DL-asparagine, L-histidine, L-hydroxyproline and DL-tryptophan cannot. Gelatin liquefaction, milk coagulation and nitrate reduction are positive; cellulose and starch hydrolysis, hydrogen sulfide and melanin production, and catalase, urease and oxidase activities are negative. Resistant to ampicillin $(10 \mu \mathrm{g})$, carbenicillin $(10 \mu \mathrm{g})$, cefuroxime $(30 \mu \mathrm{g})$, ceftriaxone $(30 \mu \mathrm{g})$, cephalothin (V) $(30 \mu \mathrm{g})$, cephalothin (VI) $(30 \mu \mathrm{g})$, chloramphenicol $(30 \mu \mathrm{g})$, furoxone $(30 \mu \mathrm{g})$, penicillin $(10 \mu \mathrm{g})$, piperacillin $(10 \mu \mathrm{g})$ and oxacillin $(1 \mu \mathrm{g})$, but not to cephalothin (IV) $(300 \mu \mathrm{g})$ and fortum

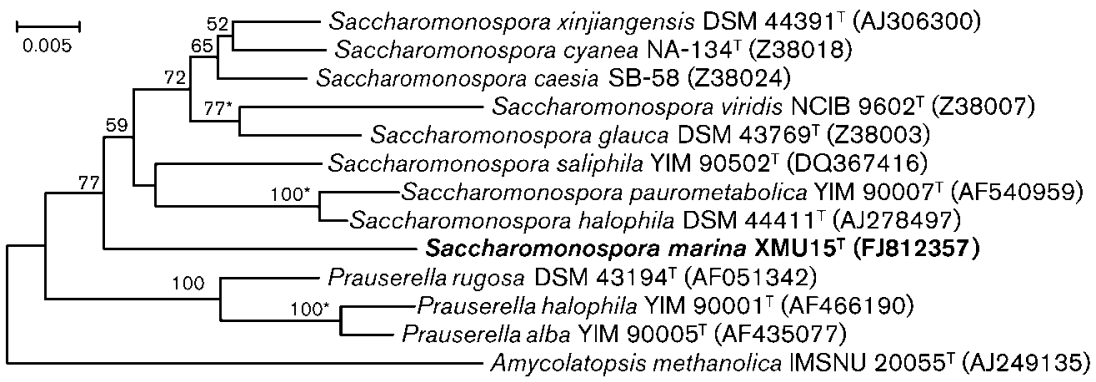

Fig. 1. Neighbour-joining phylogenetic tree derived from 16S rRNA gene sequences, showing the position of strain $\mathrm{XMU} 15^{\top}$ among species of the genus Saccharomonospora and the related genus Prauserella. Asterisks indicate branches recovered with all three methods: neighbour-joining, maximum-likelihood and maximum-parsimony. Bootstrap values (only those above 50\%) are shown as percentages of 1000 replicates. The sequence of Amycolatopsis methanolica IMSNU $20055^{\top}$ (AJ249135) was used as the outgroup. Bar, 0.5 nucleotide substitutions per $100 \mathrm{nt}$. 
$(30 \mu \mathrm{g})$. Whole cell hydrolysates contain meso-diaminopimelic acid and arabinose, galactose and ribose. The menaquinones are MK-9 $\left(\mathrm{H}_{4}\right)(89.6 \%)$ and MK- $8\left(\mathrm{H}_{4}\right)$ $(10.4 \%)$ and the phospholipids are diphosphatidylglycerol, phosphatidylglycerol, phosphatidylinositol, and phosphatidylethanolamine. Fatty acids are iso- $\mathrm{C}_{16: 0}, \mathrm{C}_{17: 1} \omega 6 c, \mathrm{C}_{15: 0}$, $\mathrm{C}_{16: 0}, \mathrm{C}_{17: 1} \omega 8 c$, iso- $\mathrm{C}_{16: 1} \mathrm{H}, \mathrm{C}_{17: 0}$, anteiso- $\mathrm{C}_{17: 0}$, $\mathrm{C}_{15: 1} \omega 6 c$ and $\mathrm{C}_{18: 1} \omega 9 c$. The DNA $\mathrm{G}+\mathrm{C}$ content of the type strain is $68.1 \mathrm{~mol} \%$.

Strain XMU15 ${ }^{\mathrm{T}}\left(=\right.$ KCTC $19701^{\mathrm{T}}=$ CCTCC AA $\left.209048^{\mathrm{T}}\right)$ was isolated from an ocean sediment sample collected from Zhaoan Bay in the East China Sea, Xiamen, Fujian province, China.

\section{Acknowledgements}

This research was supported by the National Basic Research Program of China (no. 2010CB833800), Key Project of International Cooperation (2007DFB31620), National High Technology Research and Development Program of China (nos 2006AA09Z410 and 2007AA091503) and National Natural Science Foundation of China (nos 30700015 and 30870005).

\section{References}

Al-Zarban, S. S., Al-Musallam, A. A., Abbas, I., Stackebrandt, E. \& Kroppenstedt, R. M. (2002). Saccharomonospora halophila sp. nov., a novel halophilic actinomycete isolated from marsh soil in Kuwait. Int J Syst Evol Microbiol 52, 555-558.

Chun, J., Lee, J.-H., Jung, Y., Kim, M., Kim, S., Kim, B. K. \& Lim, Y.-W. (2007). EzTaxon: a web-based tool for the identification of prokaryotes based on $16 \mathrm{~S}$ ribosomal RNA gene sequences. Int J Syst Evol Microbiol 57, 2259-2261.

Felsenstein, J. (1981). Evolutionary trees from DNA sequences: a maximum likelihood approach. J Mol Evol 17, 368-376.

Felsenstein, J. (1985). Confidence limits on phylogenies: an approach using the bootstrap. Evolution 39, 783-791.

Fitch, W. M. (1971). Toward defining the course of evolution: minimum change for a specific tree topology. Syst Zool 20, 406-416.

Greiner-Mai, E., Korn-Wendisch, F. \& Kutzner, H. J. (1988). Taxonomic revision of the genus Saccharomonospora and description of of Saccharomonospora glauca sp. nov. Int J Syst Bacteriol 38, 398405.

Hasegawa, T., Takizawa, M. \& Tanida, S. (1983). A rapid analysis for chemical grouping of aerobic actinomycetes. J Gen Appl Microbiol 29, 319-322.

Hu, R. (1987). Saccharomonospora azurea sp. nov., a new species from soil. Int J Syst Bacteriol 37, 60-61.

Hu, R., Lin, C. \& Guizhen, W. (1988). Saccharomonospora cyanea sp. nov. Int J Syst Bacteriol 38, 444-446.

Jin, X., Xu, L.-H., Mao, P.-H., Hseu, T.-H. \& Jiang, C.-L. (1998). Description of Saccharomonospora xinjiangensis sp. nov. based on chemical and molecular classification. Int J Syst Bacteriol 48, 10951099.
Kelly, K. L. (1964). Inter-Society Color Council - National Bureau of Standards Color Name Charts Illustrated with Centroid Colors. Washington, DC: US Government Printing Office.

Kimura, M. (1980). A simple method for estimating evolutionary rates of base substitutions through comparative studies of nucleotide sequences. J Mol Evol 16, 111-120.

Kroppenstedt, R. M. (1982). Separation of bacterial menaquinones by HPLC using reverse phase (RP18) and a silver loaded ion exchanger as stationary phases. J Liq Chromatogr 5, 2359-2367.

Li, W.-J., Tang, S.-K., Stackebrandt, E., Kroppenstedt, R. M., Schumann, P., Xu, L.-H. \& Jiang, C.-L. (2003). Saccharomonospora paurometabolica sp. nov., a moderately halophilic actinomycete isolated from soil in China. Int J Syst Evol Microbiol 53, 15911594.

Li, W.-J., Xu, P., Schumann, P., Zhang, Y.-Q., Pukall, R., Xu, L.-H., Stackebrandt, E. \& Jiang, C.-L. (2007). Georgenia ruanii sp. nov., a novel actinobacterium isolated from forest soil in Yunnan (China), and emended description of the genus Georgenia. Int J Syst Evol Microbiol 57, 1424-1428.

Marmur, J. (1961). A procedure for the isolation of deoxyribonucleic acid from microorganisms. J Mol Biol 3, 208-218.

Mesbah, M., Premachandran, U. \& Whitman, W. B. (1989). Precise measurement of the $\mathrm{G}+\mathrm{C}$ content of deoxyribonucleic acid by highperformance liquid chromatography. Int J Syst Bacteriol 39, 159-167.

Minnikin, D. E., O’Donnell, A. G., Goodfellow, M., Alderson, G., Athalye, M., Schaal, A. \& Parlett, J. H. (1984). An integrated procedure for the extraction of bacterial isoprenoid quinones and polar lipids. J Microbiol Methods 2, 233-241.

Nonomura, H. \& Ohara, Y. (1971). Distribution of actinomycetes in soil. X. New genus and species of monosporic actinomycetes. J Ferment Technol 49, 895-903.

Pranamuda, H. \& Tokiwa, Y. (1999). Degradation of poly(L-lactide) by strains belonging to genus Amycolatopsis. Biotechnol Lett 21, 901905.

Rivas, R., Sánchez, M., Trujillo, M. E., Zurdo-Piñeiro, J. L., Mateos, P. F., Martínez-Molina, E. \& Velázquez, E. (2003). Xylanimonas cellulosilytica gen. nov., sp. nov., a xylanolytic bacterium isolated from a decayed tree (Ulmus nigra). Int J Syst Evol Microbiol 53, 99-103.

Saitou, N. \& Nei, M. (1987). The neighbor-joining method: a new method for reconstructing phylogenetic trees. Mol Biol Evol 4, 406425.

Sasser, M. (1990). Identification of bacteria by gas chromatography of cellular fatty acids. USFCC Newsl 20, 16

Shirling, E. B. \& Gottlieb, D. (1966). Methods for characterization of Streptomyces species. Int J Syst Bacteriol 16, 313-340.

Syed, D. G., Tang, S.-K., Cai, M., Zhi, X.-Y., Agasar, D., Lee, J.-C., Kim, C.-J., Jiang, C.-L., Xu, L.-H. \& Li, W.-J. (2008). Saccharomonospora saliphila sp. nov., a halophilic actinomycete from an Indian soil. Int $J$ Syst Evol Microbiol 58, 570-573.

Tamura, K., Dudley, J., Nei, M. \& Kumar, S. (2007). MEGA4: molecular evolutionary genetics analysis (MEGA) software version 4.0. Mol Biol Evol 24, 1596-1599.

Williams, S. T., Sharp, M. E. \& Holt, J. G. (editors) (1989). Bergey's Manual of Systematic Bacteriology, vol. 4. Baltimore: Williams \& Wilkins. 